\title{
A internação psiquiátrica de Adolf Hitler
}

A psicologia e a psiquiatria fornecem freqüentemente subsídios teóricos importantes para a análise e a interpretação da arte e da história. Estas, por sua vez, podem ser profundamente influenciadas por manifestações psicopatológicas de seus autores ou atores. Embora algo distante da prática clínica diária, o estudo da interação entre psiquiatria, arte e história permite ao profissional de saúde mental uma melhor compreensão de nossa sociedade. Para contribuir neste sentido, introduzimos a partir deste número uma nova área editorial, que publicará artigos sobre "Psiquiatria, Arte e História". Para inaugurar essa seção, publicamos neste número o artigo do professor Gerhard Köpf sobre a pouco conhecida internação psiquiátrica de Adolf Hitler, em 1918, com o diagnóstico de "cegueira histérica". Neste artigo, escrito especialmente para a Revista de Psiquiatria Clínica, o professor Köpf descreve o momento histórico da internação e como o psiquiatra que tratou Hitler e todas as pessoas envolvidas com seu prontuário psiquiátrico se suicidaram ou foram mortas pela polícia secreta alemã (Geheime Staatspolizei, Gestapo) depois da ascensão de Hitler ao poder em 1933, numa tentativa evidente de esconder o passado psiquiátrico do Führer.

O professor Gerhard Köpf nasceu em 1948 em Pfronten/ Allgäu, na Alemanha. Estudou germanística e, como ouvinte, medicina na Universidade de Munique. Em 1974, concluiu seu doutorado com a tese sobre Sprachskepsis, no qual discute as limitações da linguagem falada para expressar estados psíquicos. A partir daí, lecionou em várias universidades de diversos países; de 1981 a 2003, ocupou a cátedra de Literatura Aplicada na Universidade de Duisburg, e desde 2001 é professor convidado na Clínica de Psiquiatria da Universidade de Munique. Além de vinte livros científicos, Köpf publicou, como escritor, doze romances, contos e ensaios, além de ter trabalhado para produções de rádio, televisão e cinema. A filmagem de seu romance $O$ Caminho (Die Strecke), com o título O Último Passeio de Waller, ganhou em 1989 o Prêmio Alemão de Cinema. Sua obra literária foi traduzida em sete línguas, tendo recebido inúmeros prêmios. O professor Köpf é membro do PEN e da Academia Bávara de Belas-Artes. Seu trabalho científico concentra-se nas interações entre a psiquiatria e a literatura. Seguramente, um autor altamente qualificado para inaugurar a nova área editorial da Revista de Psiquiatria Clínica. 